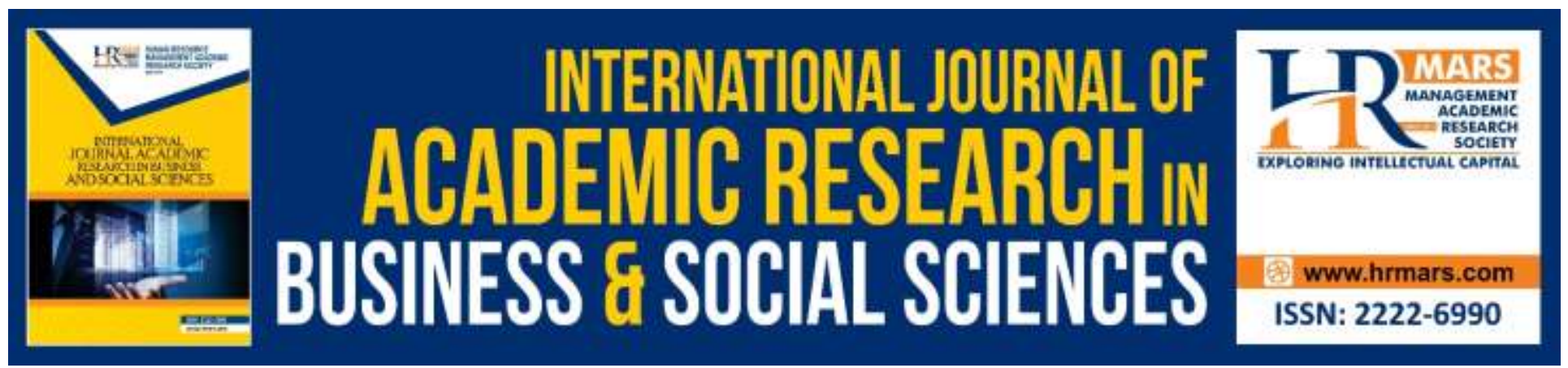

\title{
Analysis of Teacher Readiness towards Higher Order Thinking Skills (HOTS) Integration in Preschool Teaching and Learning (TNL)
}

Sandra Suffian, Suppiah Nachiappan

To Link this Article: http://dx.doi.org/10.6007/IJARBSS/v9-i7/6134

DOI: $10.6007 /$ IJARBSS/v9-i7/6134

Received: 19 May 2019, Revised: 18 June 2019, Accepted: 05 June 2019

Published Online: 28 July 2019

In-Text Citation: (Suffian \& Nachiappan, 2019)

To Cite this Article: Suffian, S., \& Nachiappan, S. (2019). Analysis of Teacher Readiness towards Higher Order Thinking Skills (HOTS) Integration in Preschool Teaching and Learning (TNL). International Journal of Academic Research in Business and Social Sciences, 9(7), 417-423.

Copyright: (C) 2019 The Author(s)

Published by Human Resource Management Academic Research Society (www.hrmars.com)

This article is published under the Creative Commons Attribution (CC BY 4.0) license. Anyone may reproduce, distribute, translate and create derivative works of this article (for both commercial and non-commercial purposes), subject to full attribution to the original publication and authors. The full terms of this license may be seen at: http://creativecommons.org/licences/by/4.0/legalcode

Vol. 9, No. 7, 2019, Pg. 417 - 423

Full Terms \& Conditions of access and use can be found at http://hrmars.com/index.php/pages/detail/publication-ethics 


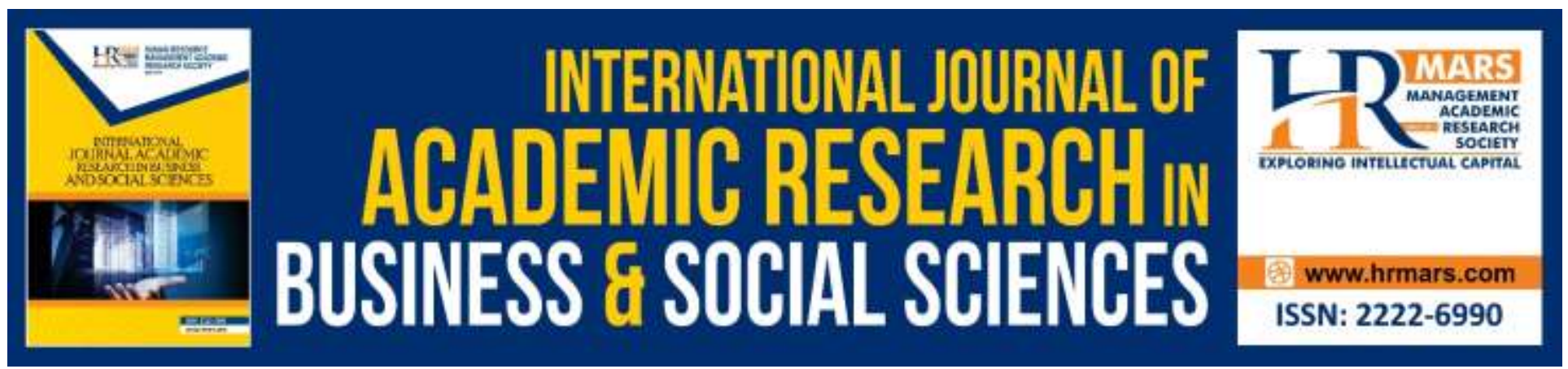

\title{
Analysis of Teacher Readiness towards Higher Order Thinking Skills (HOTS) Integration in Preschool Teaching and Learning (TNL)
}

\author{
Sandra Suffian, Suppiah Nachiappan \\ Faculty of Human Development, Sultan Idris Education University, 35900 Tanjung Malim, Perak, \\ Malaysia \\ Email: sandrasuffian@gmail.com,suppiah@fpm.edu.upsi.my
}

\begin{abstract}
The purpose of the study is to identify the HOTs elements in writing daily lesson plan, the presence of HOTs in teaching and learning preschool teachers, the problems faced by preschool teachers in implementing TnL through HOTs integration in preschool as well as identifying the preschool teacher's readiness to integrate HOTs in preschool TnL. The sample of the study involved fifteen preschool teachers served under Ministry of Education Malaysia from Larut, Selama and Matang District and managed to use National Preschool Standard Curriculum Revision 2017 as a reference in implementing $T n L$ in preschool. The research method was qualitative using the instruments such as observation checklist, interview form and document analysis for data collection. The data was analyzed using the Hermeneutics Method which is interpretation of text to metatext. The findings show that teachers' readiness to integrate HOTs especially in terms of skills, knowledge and application of HOTs is still less particularly the teachers who teach in rural schools. The implication of the study is that the Ministry of Education Malaysia / State Education Department / District Education Office / Principals should provide periodic courses and workshops as well as monitoring the TnL activities provided by the teachers.
\end{abstract}

Keywords: Preschool, Teacher Readiness, HOTs, Hermeneutics method, TnL

\section{Introduction}

A paradigm shift has been implemented by the government through the transformation of education in the Malaysian Education Development Plan (2013-2025) to pave the way towards the formation of educated people. This change is made entirely involving preschool education so that higher education by placing Higher Order Thinking Skills (HOTS) as one of the key aspects focused on teaching.

To stimulate structural thinking and focus on preschools, HOTS has been explicitly stated in the National Preschool Standard Curriculum so that teachers can translate into preschool teaching 
and learning. HOTS is the ability to apply knowledge, skills and values in making reasoning and reflection to solve problems, make decisions, innovate and create something (Ministry of Education Malaysia, 2016).

This study touches on the issues that arise regarding preschool teachers' readiness to implement teaching and learning in integrating HOTS at the level of preschool students under the supervision of the Ministry of Education Malaysia. Several issues have been identified that make the process of integrating HOTS in teaching and learning in preschool difficult.

Among the problems inherent in integrating HOTS in preschool, as noted by Fernández and Feliu (2017), is that when preschool teachers enter the classroom, the teaching methods they use are often quite traditional and do not lead to the development of HOTS among students. This is because teachers focus only on teaching and learning aspects of artistic education but less on methodological and philosophical training.

Based on the literature review, most of the focus of previous studies are more focused on the primary school level (Othman \& Kassim, 2017); (Hassan, Mustapha, Yusuff \& Mansor, 2017) high school level (Peng \& Nadaraja, 2016); (Ismail \& Mahamod, 2016) as well as higher education institutions (Ali \& Noordin, 2010); (Yusoff, Osman, Shaari \& Ghazali, 2012). In the context of preschool education, the lack of recent research focuses on the readiness of preschool teachers to integrate HOTS in teaching and learning in preschool. Therefore, this study is important to provide some information on the extent to which preschool teachers are prepared for the integration of HOTS in teaching and learning at preschools. This study can also raise awareness among teachers on the importance of HOTS elements to implement in teaching and learning.

\section{Literature Review}

According to Newman (1990), HOTS is defined as the challenge and the widespread use of the mind when one needs to make interpretation, analyze or manipulate information to answer a question. However, in the context of this study, HOTS is defined as the thought of up to three top levels in the Revision Bloom Taxonomy (Anderson \& Krathwohl, 2001) which analyzes, evaluates and creates. In Malaysia, however, HOTS refer to the four top taxonomies, namely applying, analyzing, evaluating and creating (Ministry of Education Malaysia, 2013).

According to Ministry of Education Malaysia (2016), National Preschool Standard Curriculum has explicitly explained that thinking skills as one of the 21st century skills that must be mastered by preschoolers today. There are four categories of thinking level at the preschool level namely, applying, evaluating, analyzing and creating. 21st century skills aim to shape pupils more readily in solving daily problems and being able to compete globally as explicitly stated in the National Preschool Standard Curriculum.

The Ministry of Education Malaysia (2016) has outlined some suitable TnL strategies based on the development of preschoolers and can be applied by preschool teachers that is student-centered learning, learning through play, inquiry-based learning, integrated approach, theme approach, project-based learning, contextual and learning based on various intelligence. Due to the level of thinking of different preschoolers, they are free to choose what is appropriate when the teaching and learning process takes place. Furthermore, each student has its own strength and weaknesses. 
Nooriza and Effandi (2013) found that some teachers are less prepared to implement teaching and learning by integrating high-level thinking skills. This is due to the diversity of teaching strategies of HOTS that teachers use.

According to Rosnani and Suhailah (2003), their study found that courses or training related HOTS were not introduced to teachers during teacher training as well as during service. This proves that the knowledge and exposure given to the teacher is still very poor and should be further enhanced in an effort to create a new generation of skilled thinkers.

\section{Research Objectives}

Generally, this study is conducted to analysis teacher readiness in implementing higher order thinking skills on it. In particular, the objectives of this study are as follows:

i) Identify elements of Higher Order Thinking Skills in Preschool Daily Lesson Plans.

ii) Identify the method of teaching and learning of teachers through HOTS integration in preschool.

iii) Identify problems faced by preschool teachers in implementing TnL through HOTS integration in preschool.

iv) Identify the extent of readiness of preschool teachers in integrating HOTS in teaching and learning in preschools on aspects of knowledge, attitudes and skills.

\section{Methodology}

This study is based on the design of the study using Hermeneutics analysis as a methodology used to interpret the answer text through observation, document analysis (Daily Lesson Plan) and interviews with preschool teachers to study and analyze the answers of preschool teachers in implementing $\mathrm{TnL}$ through the integration of HOTS in preschool.

Hermeneutics focuses on the text as a data source (Bloomberg \& Volpe, 2012), an example of a text consisting of interview transcripts, diaries, essays, letters and so on (Suppiah, 2017). The result of interpretation of the text referred as metatext. This metatext needs four key principles as stated by Loganathan (1992), the Principle of Consistency, the Principle of Substantiation, the Principle of Inadequacy and the Principle of Distinctiveness. If the metateks meet these principles, then this metatext is accepted and if it is otherwise, then the metatex should be rejected.

\section{Research Outcome}

\section{Higher Order Thinking Skills Elements in Preschool Teacher's Daily Lesson Plans}

The findings of the document analysis show that teachers have expressed the HOTS element in Daily Lesson Plans writing. However, the teacher does not specify the HOTS element used specifically in each TnL step starting from the induction set until the end. The researcher also found that teachers often mention the HOTS elements such as questioning. This shows that teacher knowledge about HOTS elements that need to be implemented in TnL is still shallow. The findings of this study were supported by Abdullah et al. (2015) found that teachers are aware of the basics of Bloom's Taxonomy cognitive level but they still do not understand the difference and function of each level in Lower Order Thinking Skills (LOTS) and HOTS. 


\section{HOTS Presence in Preschool Teacher TnL}

Teachers use effective teaching strategies such as group activity, exploring beyond the classroom environment and storytelling techniques. Teachers prefer to use bubble maps (I-Think) in delivering TnL to stimulate student thought. In addition, teachers also use question and question techniques as a tool of thinking. Teachers often use materials as a teaching aid as this approach can provide an effective experience in preschool life. According to Anida, Dahlia, Zulkifli and Ahmad (2016) effective use of stimulants is crucial to improving the cognitive performance of preschool children.

\section{Problems Faced by Preschool Teachers on HOTS Integration in Preschool TnL}

Problem faced by preschool teachers are time constraints in providing the right learning topic and search material, not ready in implementing HOTS due to lack of exposure on HOTS concepts, teaching aids that are already far behind and no internet facility to facilitate teachers to find additional information. According to Mistima et al., (2015) teaching and learning in Malaysia is still monopolized by lower order thinking rather than teaching and learning outcomes. The reality is, less teachers are given exposure on teaching methods and pedagogical thinking skills. This proves that there is a problem to be studied for the good of the Malaysian educational institution itself.

\section{The Willingness of Preschool Teacher to Integrate HOTS in TnL in Preschool}

The willingness of teachers to manage TnL includes subject knowledge, skills to teach subject content and teacher attitude towards their responsibilities. There are some teachers who have not mastered the strategy to teach thinking techniques to their students. Teachers also assumed that HOTS integration is less appropriate at the preschool level because it is still too early. The study of Norsita and Zainal (2014) found that the attitude of the teacher plays an important role in determining the preparation, preparation of emotional material and the emotion of teachers that will affect the teaching style of the teacher, the emotions and learning styles of children. According to Ruzaini (2015), teachers as the main drivers in the school need to be prepared from the knowledge of skills and positive attitude so that $\mathrm{TnL}$ can run smoothly and effectively.

\section{Conclusion}

Early childhood education is a great time and is very important because the education applied can have a long-term impact on the development of children's mental, thinking and social skills. Therefore, teachers play a role in determining their teaching and learning in order to have HOTS elements that can train HOTS among children as early as early childhood.

It is hoped that this study will open the minds of educators on the importance of HOTS being applied through teaching in schools to produce a generation of critical thinking. Also, HOTS are also a shield for the individual in the increasingly fierce global competition of the 21st century. Therefore, the emphasis on integrating HOTS at the preschool level should be strengthened so that teachers, schools, and those involved directly and indirectly do not take this matter lightly. 
INTERNATIONAL JOURNAL OF ACADEMIC RESEARCH IN BUSINESS AND SOCIAL SCIENCES

Vol. 9, No. 7, July, 2019, E-ISSN: 2222-6990 @ 2019 HRMARS

\section{Acknowledgement}

The researcher would like to thank the Sultan Idris University of Education for giving an opportunity to learnt and developed skills in research area. Researcher also grateful to the Ministry of Education for giving permission to conduct research studies at selected schools.

\section{References}

Abdullah, A. H., Aris, B. Saud., M. S. Boon, Y., \& Ali, A. S.A. (2015). Higher Order Thinking Skills (HOTS): Issues and Challenges in the Curriculum Aspects. Pedagogy and Assessment. National Seminar of Council of Deans of Public University Education 2015, September 14-15, 2015, p. 77-88.

Ali, M., \& Noordin, S. (2010). The relationship between critical thinking skills and academic achievement among Malaysian university technology education students. Sains Humanika, 52(1).

Anderson, L. W., \& Krathwohl, D. R. (2001). A taxonomy for learning, teaching, and assessing: $A$ revision of Bloom's taxonomy of educational objectives. New York: Longman.

Anida, S., Dahlia, J., Zulkifli, O., \& Khair, A. M. N. (2016). Preschool Language Proficiency Based on Assesment Inventory Organized Skills. International Journal of Language Education and Applied Linguistics, 4: 93-106.

Bloomberg, L. D., \& Volpe, M. (2012). Completing your qualitative dissertation: A road map from beginning to end (2nd Ed.). Thousand Oaks, California: SAGE Publication, Inc.

Fernández, M., \& Torruella, F. M. (2017). Reggio Emilia: An Essential Tool to Develop Critical Thinking in Early Childhood. Journal of New Approaches in Educational Research, 6(1), 50-56. doi: 10.7821/naer.2017.1.207

Hassan, M. N., Mustapha, R., Yusuff, N. A. N., \& Mansor, R. (2017). Development of Higher Order Thinking Skills Modules in Elementary School Science Subjects: Teacher Needs Analysis. Sains Humanika, 9, 1-5.

Ismail, N., \& Mahamod, Z. (2016). Attitude and Preparedness of High School Students in Higher Order Thinking Skills in Malay Language Learning. Jurnal Pendidikan Bahasa Melayu, 6(2), 59-67.

Loganathan, K. (1992). Hermeneutic Analysis of Discourse. Thiruvananthapuram: International School of Dravidian Linguistics.

Ministry of Education Malaysia. (2013). Malaysian Education Blueprint 2013-2025 (Preschool to Secondary School). Putrajaya: Federal Government Administrative Centre.

Ministry of Education Malaysia. (2016). National Preschool Standard Curriculum: Standard Curriculum and Assessment Document. Kuala Lumpur: Curriculum Development Division.

Newmann, F. M. (1990). Higher order thinking in teaching social studies: a rationale for the assessment of classroom thoughtfulness. Journal of Curriculum Studies, 22(1), 41-56.

Nooriza, K., \& Effandi, Z. (2015). The Integration of Higher Order Thinking Skills in Mathematical Teaching and Learning: Analyze the Teacher's Needs. Journal of Mathematical Education, 3 (1): 1-12.

Norsita, A., \& Zainal, M. (2014). Preliminary survey of children's teacher interactions in the promotion of creative thinking of preschool children. Proceeding of the Social Sciences Research ICSSR 2014. 
INTERNATIONAL JOURNAL OF ACADEMIC RESEARCH IN BUSINESS AND SOCIAL SCIENCES

Vol. 9, No. 7, July, 2019, E-ISSN: 2222-6990 ¿ 2019 HRMARS

Othman, M. S. B., \& Kassim, A. Y. B. (2017). The Effectiveness of Beginning Teaching with Higher Order Thinking Skills (HOTS) in Perak State Primary Education. O-JIE: Online Journal of Islamic Education, 4(2), 23-35.

Peng, C. F., \& Nadaraja, S. (2016). Implementation of Creative and Critical Thinking Skills in Teaching and Learning Literature Components in Secondary Schools. Jurnal Pendidikan Bahasa Melayu, 4(2), 10-24.

Rosnani, H., \& Suhailah, H. (2003). The teaching of thinking in Malaysia (1st Ed.). Kuala Lumpur: Research Centre, International Islamic University Malaysia.

Ruzaini, R. (2015). The Readiness of Teachers In The Implementation Of The Linus Program In Primary School. Tanjong Malim: Sultan Idris Education University (Unpublished undergraduate thesis).

Mistima, S. M., Mazlini, A., Lee, M. F. N. A., Nidzam, C. A. \& Marzita, P. (2015). Confirmatory factor analysis of learning environment instrument among high performance school students. Creative Education 6: 640-646.

Suppiah, N. (2017). Cognition and Affection Process: Hermeneutical Pedagogical Methods and Interpretations (5th ed.). Tanjong Malim: Penerbit Universiti Pendidikan Sultan Idris.

Yusoff, M., Osman, R., Shaari, A. S., \& Ghazali, M. I. (2012). Learning Skills among Students in the Field of Education. Seminar Kebangsaan Majlis Dekan Pendidikan IPTA. 